\title{
IAMJ
}

INTERNATIONAL

AYURVEDIC

MEDICAL JOURNAL

ISSN: 23205091

Impact Factor: 5.344

\section{CONTROVERSIAL DRUGS IN SADHARANA RASA}

\section{Shweta S Nayak}

Associate Professor, Department of Rasashastra \& Bhaishajya Kalpana,

Ashwini Ayurvdic Medical College Postgraduate Studies and Research Centre, Maralur, Tumkur,

Karnataka, India

Corresponding Author: snshwetu@gmail.com

https://doi.org/10.46607/iamj3208082020

(Published online: August 2020)

Open Access

(C) International Ayurvedic Medical Journal, India 2020

Article Received: 29/06/2020 - Peer Reviewed: 24/07/2020 - Accepted for Publication: 24/07/2020

Check for updates

\begin{abstract}
Rasashastra study of metal and mineral medicines is one of the oriental sciences which comes in the domain of god Shiva -the important deity of Rasashastra. It is understood that the term Rasashastra denotes Parada, Maharasa, Uparasa and Sadharana Rasa. Rasdravyas are the group of a drug which processed with Parada and helps to achieve Lohavada and Dhatuvada. Sadharana Rasa are less and commonly useful in mercurial preparation. The word controversy refers to a confusion and unauthenticated or unjustified version of subjects. Due to lack of difference opinion of scholar regarding identification, properties drugs, leads to reject in quality of Rasa preparations. It is creating problem for uniformity in standardization of Rasaushadhies. Standardization is required to rule out the state of uncertainty regarding the identification and use of drugs, to meet the challenges of new millennium with increasing demand on our products globally.
\end{abstract}

Keywords: Sadharana Rasa, Rasadravya, controversy, Rasashastra, Standardization

\section{INTRODUCTION}

There are different types of drugs found in nature has been used by Ayurvedic science - a ancient system in the field of medicine. After the Samhita Kala when Rasashastra evolved, it introduced use of metal \& 
minerals for both internal \& external treatment. Dehavada \& Dhatuvada are the 2-dimensional motivation of Rasashastra which helps to attain Moksha by using mercury mainly which is processed with other $R a$ sadravyas. Sadharana rasa is also plays an important role in Parada Samskara. According to description all Sadharana Dravya are available in ancient time, but controversies of the drugs started after medieval period of Ayurveda. Because of lack of knowledge, brief explanation \& non availability of drugs, it is creating problem for uniformity in standardization \& reliability of Ayurveda products. To come up with standard Rasa preparation there is need to highlight the area of controversies in the field of Rasashastra.

Sadharana Rasa- The group of minerals which is less importance than Maharasa and Uparasa which includes all pranija, Sudha, Lavana with Khanija drugs \&commonly useful in ParadaSamskara called as Sadharana Rasa.

They are 8 drugs: Kampillaka, Gauriphashana, Navasadara, Kaparda, Vanhijara, Girisindoora, Hingula, Mruddarashrunga. ${ }^{1}$

Controversy in sadharana Rasa-

- Kampillaka

- Navasadara

- Vanhijara

- Girisindoora

A. Kampillaka: It is a vegetative source which is highly purgative in Rasashastra.

\section{Controversy:}

No controversies as such.

a. As per text it is one of vegetable drugs. Generally, found in Sourastra (Gujarat state). It is Phala Raja of plant Mallatous Phillipinesis Muell. ${ }^{1}$

b. It is like brick red dust $\&$ highly purgative found in Saurastra. ${ }^{2}$

c. It is shiny mud which is Raktavarna available in hilly region of Saurastra. ${ }^{3}$

d. It is shiny brick colour mineral found in saurastra. $^{4}$

e. It resembles Vidanga phala\& varies in properties. It will lighter than weight of Kampillaka. ${ }^{5}$ f. Some people consider euphorbia tirucallani plant (Indian tree spurge) as Kampillaka. The whole plant is full of latex $\&$ is poisonous. ${ }^{6}$

g. There are 2 sources- 1. Herbal 2. Mineral. Kampillaka of Rasashastra \& DravyaGuna may entirely different. As per Rasashastra it may be a variety of clay used in Gujarat as purgative. ${ }^{7}$

B. Navasadara: It is yellowish white in colour having Kshariya \& Amla taste. It is used for Swarna shodhana \& also for Parada Jarana mainly.

\section{Controversy: found in source.}

a. It is Kshara, which is found in Kareera \& Pilu wood, when a state of decomposition called as Chullika Lavana. ${ }^{8}$

b. It is the pale, Saltish \& light thing which is sometime found deposited on burnt bricks. ${ }^{9}$

c. The stool of man, camel etc is to be dissolved with water \&filtrate through a piece of cloth slowly \& then dried up by means of heat, the product being Navasadara. ${ }^{10}$

d. Navasara is obtained by residue Bhasma obtained by stool of man, camel etc after burning it has mentioned in Kshara Gana. ${ }^{11}$

e. In Europe it is obtained from man's urine called Narasara. It also obtained from volcanic mountain of sisali naturally. ${ }^{12}$

f. It is also called as Vidalavana. ${ }^{13}$

g. In Punjab it is extracted from mud. ${ }^{14}$

h. Navasadara mentioned under Kshara Varga. ${ }^{15}$

C. Agnijara: It is obtained from the seashore $\&$ is a Jaraayu of Agninakra (a sea animal). Rasranva mentioned about Agnijara first time.

\section{Controversy:}

a. It is a product of Agninakra fish's chorion. ${ }^{16}$

b. It is uterine expulsion of a kind of shark thrown on the beach by the waves of sea. It is dried when exposed to sun. ${ }^{17}$

c. It is a type of tree found near western seashore which is used as medicine. Amongrakta, peeta, shweta, Krishna - Red variety is considered as medicine. ${ }^{18}$

d. According to modern view, it occurs a biliary secretion of intestine of sperm whale $\&$ can be found floating upon sea or in sand near coast. 
e. Found in abdomen of whale, which is solid, waxy, flammable substance, dull grey/black colour produced in digestive system. ${ }^{19}$

f. It is intestinal part of whale. Due to ingestion of some grass in sea, the intestine of whale gets obstructed which leading ti death of whale. After death, the intestinal part starts decaying and float on the sea. ${ }^{20}$

g. When whale fish died due to obstruction of hard stool, which comes out from the intestine of dead fish\& floating on seawater \& on drying through sunrays it is known as Amber.

h. It is intestinal stone of whale shark. Due to this shark died \& stone comes out in sea water and dried up by rays. ${ }^{21}$

D. Girisindoora: In big mountains, mercury in small quantity comes out of cracks in rocks which is dry $\&$ red in colour.

\section{Controversy:}

a. It is red colour dry mercury found in mountain inside the rocks. ${ }^{22}$

b. It is red coloured exudates coming out off the rocks of big mountain $\&$ dried with sunrays.

c. Girisindoora is probably a compound of mercury and oxygen which occurs rarely in mineral from mixed with other minerals or in between the rocks. ${ }^{23}$

d. It is obtained by lead compound which look like red called as Nagasindoora. ${ }^{24}$

e. According to D A kulkarni, it is a compound of $\mathrm{Hg} \&$ oxygen and is rarely found in rocks along with other minerals. Nowadays it is obtained by the name of sipicand in modern shops \& prepared artificially. To differentiate it from Naga sindoora ancient scholars of Rasashastra might have added the adjective Giri to it. It may be known as red oxide of mercury.

f. In modern mercuric oxide obtained by heating mercury to its boiling point in air. It is produced in small quantity by the prolonged heating. It is orange yellow in colour, odourless, amorphous powder insoluble in water. ${ }^{25}$

g. In market, in the name of sindoora available is prepared by lead peroxide. It is available natural and artificial. When litharge is heated up to $450^{\circ} \mathrm{C}$ in presence of oxygen and form red colour on external surface. This is known as Nagasindoora. ${ }^{26}$

h. It is also prepared by lead kept in crucible or heating pan heating and open air. ${ }^{27}$

i. According to Dr. Vaman Ganesh Desai, it is Rakta Bhasma, a type of parada Bhasma (mercuric oxide) which is prepared by Urdhwapatana kriya called as Calcined mercury. ${ }^{28}$

\section{DISCUSSION}

Controversy about authentic drugs dealt in classical texts led a cause of substitution $\&$ create a problem for standardization of rasa practices \& herbo-mineral products. Substitution of drug is need of time although substitution should only do for endangered drugs. The major constituents should not substitute. Kampillaka, there is no much controversy observed. As per definition it is a drug which resembles brick powder available in surasthra. Many of authors accepted as, it is a PhalaRaja of plant mallatous phillipinesis muell obtained specially in Saurastra in ancient time, nowadays this plant grows in different part of country. In market for the profit purpose brick powder is usually added. In case of Navasadara, there is different opinion in source- plant/animal/mineral. It is available in natural \& artificial. In India, Navasadara is prepared by Kshara of burnt wood of Kareera \& Pilu \& found deposited on burnt bricks in Punjab. In other country by using animal source as well as human byproduct it is prepared. Agnijara, it is obtained from sea animal. Here doubt arises about which part of sperm whale is considered as Agnijara? As per modern view, it is a solid, waxy, flammable substance of dull grey or blackish colour produced from in the digestive system of sperm whale which has fecal odour when fresh; it acquires sweety, earthy scent as its ages. Girisindoora is a rare mineral in ancient time. In the name of sindo$r a$ what available in market is prepared by lead compound is not having the same quality of Girindoora. It is Tridoshashamka, used in eye disorder and helps to attain DehaSiddhi \& LohaSiddhi. But market available Sindoora is used only in external treatment. 


\section{CONCLUSION}

Descriptions about Rasadravyas are clear in Rasashastra. Controversy arises mainly due to synonym, definition by different views of Acharya. Proper identification of drug source is a great problem till date. Controversy about authentic drugs should be resolved by research:

1) Kampillaka widely used nowadays is of herbal origin which is acceptable to most of authorities.

2) Navasadara is available both natural \& artificial. It differs from Vida Lavana.

3) Present day according to availability Agnijara is of animal origin- a product of sperm whale.

4) Girisindoora is red oxide mercury naturally occurring. But in market Nagasindoora is available in the name of Girisindoora.

5) For quality, safety, standardization purpose of rasa medicines the problem related drugs should be resolved for its worldwide acceptance.

\section{REFERENCES}

1. Trayambaknathsharma. Rasamitra. Choukambha Sanskrit series Office, Varanasi; $2^{\text {nd }}$ chapter. 96p.

2. Dattatreya Ananta Kulakarni. Rasa Ratna Samucchaya: Vijnanabodhini Hindi translation. Meharchand Lachaman Das publication, New Delhi; Chapter 3/122. 64p.

3. Bhajandas Swami Dadupanath, Rasadarpana, $1^{\text {st }}$ Part, Nath Pustak Bhandara, Rohtak Parishista, $6^{\text {th }}$ chap,369p

4. Pt. Dattaram Choube. Brihat Rasa Rajasundara. Choukamba Orientale, Varanasi; 182p.

5. Darmanand Sharma. Rasaratna Samucchaya. Choukamba orientalia, Varanasi; 3/128. 55p.

6. https//et.m.wikipedia.org/wiki/kampillaka

7. Dr.J L NShastri. Dravyaguna Vignana-vol 2. Choukhambhaorientalia, Varanasi; reprint edition.

8. Dattatreya Ananta Kulakarni. Rasa Ratna Samucchaya: Vijnanabodhini Hindi translation. Meharchand Lachaman Das publication, New Delhi; 66p.

9. Dattatreya Ananta Kulakarni. Rasa Ratna Samucchaya: Vijnanabodhini Hindi translation. Meharchand Lachaman Das publication, New Delhi; 66p.

10. Bhudeb Mukharjee. RasaJalaNidhi- vol 2. Choukhambha publishers, Varanasi; $4^{\text {th }}$ edition; $215 \mathrm{p}$.

11. Sri Gularaj Sharma Mishra. Ayurveda Prakasha. Choukambha Bharathi Academy, Varanasi; 2chapter shloka; 339p.

12. Damodar Joshi. Textbook of Rasashastra. Choukambaorientalia, Varanasi; reprint edition; 239p.
13. Dattatreya Ananta Kulakarni. Rasa Ratna Samucchaya: Vijnanabodhini Hindi translation. Meharchand Lachaman Das publication, New Delhi; 67p.

14. Mishra siddinandan. Rasendrachudamani. Choukambaorientalia, Varanasi; $1^{\text {st }}$ edition -1984; 193p.

15. Pt. Kashinath Sharma Mishra. Rasa Tarangini. Mothilal Banarasi Das, Delhi; 11 edition; $4^{\text {th }}$ chapter; 326-320p.

16. Dattatreya Ananta Kulakarni. Rasa RatnaSamucchaya: Vijnanabodhini Hindi translation. Meharchand Lachaman Das publication, New Delhi; 66p.

17. Dr. P. J Tottam. Modernizing Ayurveda. Sura Books pvt Ltd; $1^{\text {st }}$ Edition; 39p.

18. Kaviraj Umeshachandra Gupta Kaviratna. Vaidyakasabdasindhu. Shashibhushanabhatt acharya, Calcutta; 6p.

19. https//et.m.wikipedia.org/wiki/ambergreis

20. www.wjpr.net/agnijara.

21. Trayambaknath sharma. Rasamitra. Choukambha Sanskrit series Office, Varanasi; $2^{\text {nd }}$ chapter.101p.

22. Dattatreya Ananta Kulakarni. Rasa Ratna Samucchaya: Vijnanabodhini Hindi translation. Meharchand Lachaman Das publication, New Delhi; 67p.

23. Dr. Damodar Joshi. Textbook of Rasashastra. Choukhambhaorientalia, Varanasi; reprint edition. 244p.

24. Bhudeb Mukharjee. RasaJala Nidhi vol 2. Choukhambha publishers, Varanasi; $4^{\text {th }}$ edition.222p.

25. https//et.m.wikipedia.org/wiki/mercuric oxide

26. Pt. Kashinath Sharma Mishra. Rasa Tarangini. Mothilal Banarasi Das, Delhi; 11 editions. 21 chapter. 547p.

27. Dr. Damodar Joshi. Rasamritam. Chaukhambha Sanskrit Bhavan, Varanasi $2^{\text {nd }}$ edition. 2003.18 chapter. $77 \mathrm{p}$.

28. Vaidya Santosh Kumar Sharma. Rasa - Bhaishajya Vigyana. 11 edition. Scheme, Jaipur; $5^{\text {th }}$ chapter. 223p.

\section{Source of Support: Nil \\ Conflict of Interest: None Declared}

How to cite this URL: Shweta S Nayak: Controversial drugs in Sadharana Rasa. International Ayurvedic Medical Journal \{online\} 2020 \{cited August, 2020\} Available from: http://www.iamj.in/posts/images/upload/4233 4236.pdf 